\title{
KARAKTERISTIK MORFOLOGI PLASMA NUTFAH SORGUM DARI BEBERAPA DAERAH POTENSIAL SUMATERA BARAT
}

\section{MORPHOLOGICAL CHARACTERISTICS OF SORGUM NUTFAH PLASMA FROM SOME POTENTIAL REGIONS OF WEST SUMATERA}

\author{
Yun Sondang ${ }^{1 *}$, Yulensri ${ }^{2)}$ \\ ${ }^{1,2)}$ Dosen Budi daya Tanaman Pangan, Politeknik Pertanian Negeri Payakumbuh, Kab. Limapuluh Kota, \\ Sumatera Barat, Indonesia \\ *penulis korespondensi \\ 1)silitongayun27@gmail.com,2)iyulensri@gmail.com
}

\begin{abstract}
Abstrak
Sorgum (Sorghum bicolor (L.) Moench) merupakan tanaman serealia yang potensial untuk dibudidayakan dan dikembangkan sebagai sumber karbohidrat. Tujuan penelitian adalah mengidentifikasi morfologi dan varietas tanaman sorgum dari beberapa daerah potensial Sumatera Barat untuk dijadikan sebagai sumber plasma nutfah. Penelitian dilaksanakan di Kabupaten Limapuluh Kota, Kota Payakumbuh, dan Kabupaten Sijunjung selama enam bulan mulai dari bulan Juni-November 2020. Pemilihan lokasi ditentukan berdasarkan hasil survei pendahuluan. Penelitian telah dilaksanakan dengan menggunakan metode deskriptif untuk memperoleh gambaran secara keseluruhan dari ciri-ciri sampel tanaman dan pengumpulan sumber plasma nutfah. Pengamatan dilakukan terhadap karakteristik morfologi tanaman pada fase vegetatif dan generatif dengan berpedoman pada buku deskripsi tanaman sorgum. Hasil menunjukkan perbedaan antara ciri morfologi di lapangan dengan deskripsi yang ada dalam hal sifat tanaman, tinggi tanaman, warna daun, tulang daun, sifat malai, bentuk malai, panjang malai mulai dari leher malai, bentuk dan warna leher malai
\end{abstract}

Kata Kunci: morfologi, plasma nutfah, sorghum, varietas

\begin{abstract}
Sorghum (Sorghum bicolor (L.) Moench) is a cereal crop that has the potential to be cultivated and developed as a source of carbohydrates. The aim of the study was to identify the morphology and varieties of sorghum from several potential areas of West Sumatra to serve as a source of germplasm. The research was conducted in Limapuluh Kota Regency, Payakumbuh City, and Sijunjung Regency for six months starting from JuneNovember 2020. The location selection was determined based on the results of a preliminary survey. Research has been carried out using descriptive methods to obtain an overall picture of the characteristics of plant samples and the collection of germplasm sources. Observations were made on the morphological characteristics of plants in the vegetative and generative phases by referring to the sorghum plant description book.
\end{abstract}

Keyword: morphology, germplasm, sorghum, varieties

\section{Pendahuluan}

Sorgum (Sorghum bicolor (L.) Moench) merupakan salah satu tanaman serealia yang potensial untuk dibudidayakan dan dikembangkan, khususnya pada daerah-daerah marginal dan kering (Prassad and Staggenborg, 2013). Keunggulan sorgum terletak pada daya adaptasi yang luas, toleran terhadap kekeringan dan genangan air (water lodging), serta lebih tahan terhadap gangguan hama dan penyakit dibanding tanaman serealia lainnya (Irawan dan Sutrisna, 2011). Biji sorgum memiliki kandungan nutrisi cukup tinggi yang setara dengan jagung, sehingga dapat digunakan sebagai bahan pangan sumber kalori, karbohidrat, dan protein. Disamping biji, batang dan daun sorgum juga dimanfaatkan sebagai bahan pakan ternak alternatif. Keistimewaan 
lain, sejumlah galur unggul sorgum menghasilkan etanol (Hoeman, 2012). Suarni (2016) menyatakan Balitsereal telah mengembangkan galur sorgum manis yang mempunyai potensi tinggi untuk industri etanol.

Pertanaman sorgum banyak dijumpai pada daerah-daerah yang memiliki curah hujan sedikit sampai sedang. Keanekaragaman sorgum menunjukkan variasi dari berbagai varietas. Perbedaan varietas akan mempengaruhi pertumbuhan dan hasil tanaman sorgum (Cahyo, Hidayat, Sunyoto, dan Kamal, 2014). Varietas tanaman harus dilestarikan dalam bentuk koleksi sumber daya genetik (Plasma Nutfah). Plasma nutfah dapat digunakan untuk bahan persilangan antar galur untuk program pemuliaan. Menurut Purwanto (2000) Plasma nutfah merupakan substansi yang terdapat pada suatu kelompok mahluk hidup yang merupakan sumber sifat keturunan yang dapat dirakit untuk menciptakan jenis unggul atau kultivar yang baru.

Sorgum merupakan tanaman biji berkeping satu (monokotiledon) dengan sistem perakaran serabut (Rismunandar, 2006). Batang merupakan rangkaian dari ruas (internodes) dan buku (nodes), namun tidak memiliki kambium. Ruas batang bagian tengah tanaman umumnya lebih panjang dibanding ruas bagian bawah dan atas tanaman. Ruas paling panjang terdapat pada ujung tanaman yang berupa tangkai malai. Permukaan ruas batang dilapisi oleh sejenis lilin yang tebal dan berwarna putih, kecuali pada ujung batang. Lapisan lilin paling banyak pada bagian atas dari pelepah daun, yang berfungsi mengurangi transpirasi sehingga sorgum toleran terhadap kekeringan. Buku pada pangkal batang rata dengan ruasnya, pada bagian ini tumbuh akar tunjang dan tunas (du Plessis, 2008).

Bagian dalam batang sorgum yang sudah tua berupa gabus. Jenis sorgum manis memiliki kandungan gula yang tinggi pada batang gabusnya, sehingga berpotensi sebagai bahan baku gula (Hoeman, 2012). Batang sorgum berbentuk silinder dengan diameter bagian pangkal berkisar antara 0,5-5,0 cm. Tinggi batang bervariasi antara 0,5-4,0 m bergantung pada varietas (du Plessis, 2008). Tinggi tanaman sorgum dipengaruhi oleh jumlah dan ukuran ruas batang. Tinggi tanaman sorgum berhubungan erat dengan umur dan jumlah daun, pada tanaman berumur genjah, tinggi dan jumlah daun lebih sedikit daripada tanaman berumur dalam.

Pada beberapa varietas sorgum, batangnya dapat menghasilkan tunas baru/anakan dan tumbuh menjadi individu baru selain batang utama (Rahmawati, 2020). Pertumbuhan tunas atau anakan bergantung pada varietas dan lingkungan tumbuh tanaman sorgum. Kemampuan menghasilkan anakan dan tunas lebih banyak menjadikan tanaman sorgum bisa dipanen untuk kemudian di ratun (du Plessis, 2008). Cabang pada tanaman sorgum umumnya tumbuh bila batang utama rusak. Jumlah cabang dan anakan bergantung pada varietas, jarak tanam, dan kondisi lingkungan.

Selain batang, organ daun merupakan parameter kualitatif pada fase vegetatif yang harus diidentifikasi terutama permukaan daun dan adanya lidah daun (Slamet, Hisra, and Rajab, 2020). Morfologi daun yang berbentuk pita yang terdiri atas helai daun dan tangkai daun dengan panjang daun $1 \mathrm{~m}$ dan lebar 5-13 $\mathrm{cm}$ (Rahmawati, 2020). Pada pertemuan antara pelepah dan helaian daun terdapat ligula (ligule) dan kerah daun (dewlaps). Jumlah daun bervariasi antara 7-40 helai, bergantung pada varietas. Helaian daun berbentuk lanselot, lurus mendatar, berwarna hijau muda hingga hijau tua dengan permukaan dilapisi lilin. Tulang daun lurus memanjang dengan warna bervariasi dari hijau muda, kuning hingga putih, bergantung pada varietas (Andriani dan Isnaini, 2013).

Karakter morfologi fase generatif yang penting diamati adalah bentuk malai, kepadatan malai, bentuk sekam dan warna sekam, warna biji, bentuk biji, dan ukuran biji (Slamet, Hisra, and Rajab, 2020). Rangkaian bunga sorgum berada pada malai di ujung tanaman. Bunga sorgum secara utuh terdiri atas tangkai malai (peduncle), 
malai (panicle), rangkaian bunga (raceme), dan bunga (spikelet) (Karuppaiyan, Ram, and Meena, 2011). Dicko, Gruppen, Traoré, Berkel, and Voragen, 2006) menyatakan malai tanaman sorgum bervariasi bergantung pada varietas dan dibedakan berdasarkan posisi, kerapatan, dan bentuknya.

Biji sorgum berbentuk bulat dan bulat pipih dengan berat 25-55 mg (Dicko, Gruppen, Traoré, Berkel, and Voragen, 2006). Ukuran biji sorgum bervariasi sekitar 4,0 x 2,5 x 3,5 mm dan dikelompok menjadi biji berukuran kecil (8-10 mg), sedang (12-24 mg), dan besar (25-35 mg). Sekam pembungkus biji sorgum ada yang menutupi $25 \%, 50 \%, 75 \%$, dan $100 \%$ biji dengan warna sekam coklat muda, krem atau putih, bergantung pada varietas (Kusumawati, Putri, dan Suliansyah, 2013). Warna biji sorgum sangat bervariasi, mulai dari putih, kuning hingga merah, coklat, dan ungu. Bagian endosperma merupakan 80-84,6\% dari bobot biji (du Plessis 2008; Waniska, 2000). Biji sorgum dapat diolah menjadi pati (starch) yang berwarna putih (Irawan dan Sutrisna, 2011).

Sirappa (2003) menyatakan bahwa karakteristik morfologi varietas sorgum seperti bentuk tanaman, tinggi tanaman, kerebahan, ketahanan terhadap hama penyakit, ketahanan terhadap kondisi lahan, kandungan nira, rasa, dan umur panen akan menentukan produksi sorgum. Pada varietas tertentu, umur panen sorgum lebih cepat yaitu hanya 4 bulan dan sorgum dapat diratun sehingga dapat dipanen beberapa kali. Sihono, Human, Indriatama, Carkum, Parno, dan Tardisuseno (2015) menyatakan tingkat keragaman tanaman masing-masing galur/varietas diobservasi dengan membandingkan pengamatan di lapangan terhadap tetuanya. Dipertegas oleh Prajapati, Pahuja, Verma, and Chaudhary (2018) penanda morfologi didasarkan pada ciri-ciri yang dapat dinilai secara visual seperti sifat tanaman, bentuk organ batang daun, malai, dan biji.

Tujuan penelitian adalah untuk mengidentifikasi karakteristik plasma nutfah sorgum berdasarkan morfologi tanaman pada daerah Kabupaten Limapuluh Kota, Kota Payakumbuh, dan Kabupaten Sijunjung.

\section{Metode Penelitian}

Penelitian dilaksanakan di tiga daerah yaitu Kabupaten Limapuluh Kota, Kota Payakumbuh, dan Kabupaten Sijunjung. Pemilihan lokasi berdasarkan hasil survei pendahuluan. Penelitian dilakukan selama 6 bulan dari bulan Juni-November 2020.

Alat yang digunakan buku identifikasi tanaman sorgum, camera, meteran, penggaris besi, pinset, dan alatalat laboratorium. Bahan yang digunakan adalah kertas HVS, plastik benih klip, plastik isi $5 \mathrm{~kg}$, alkohol, serbet kain, tissu basah, dan tissu kering.

Penelitian dilaksanakan dengan menggunakan metode deskriptif untuk mendapatkan gambaran karakteristik morfologi tanaman sorgum. Selanjutnya bagian produktif (malai) dikumpul dan dijadikan koleksi plasma nutfah.

Pengamatan dan Pengumpulan Data

1. Sifat tanaman (menghasilkan anakan/ratun)

2. Tinggi tanaman pada akhir fase vegetatif $(\mathrm{cm})$

3. Jumlah daun yang membuka sempurna (buah)

4. Bentuk daun (pita/sempit)

5. Panjang daun terpanjang $(\mathrm{cm})$

6. Lebar daun terlebar $(\mathrm{cm})$

7. Sudut daun $\left(<{ }^{\circ} \mathrm{C}\right)$

8. Warna daun (hijau muda/tua)

9. Bentuk ujung daun (runcing/tumpul)

10. Permukaan daun (halus/kasar, licin/berlilin/ berbulu)

11. Tepi daun (lurus/bergelombang) 
12. Tulang daun (halus/kasar, rata/menonjol)

13. Lidah daun (ada/tidak ada)

14. Kerah daun (ada/tidak ada)

15. Umur berbunga (berbunga $50 \%$, hari)

16. Kedudukan tangkai bunga (di pucuk, tengah batang)

17. Bentuk bunga (tunggal/majemuk, bercabang)

18. Kepadatan malai (longgar, agak longgar, kompak)

19. Panjang malai $(\mathrm{cm})$

21. Leher malai (ada/tidak ada, warna dan bentuk) Bentuk malai (piramida, piramida terbalik, simetris)

22. Bentuk sekam (25\%, 50\%, 75\%, 100\% tertutup)

23. Warna sekam (coklat tua/muda)

24. Warna biji (warna, mengkilat, buram)

25. Bentuk biji (bulat pipih, ellip, ellip sempit)

26. Ukuran biji (panjang $\mathrm{x}$ lebar $\mathrm{x}$ tinggi)

27. Bobot 100 biji (g/100 biji)

28. Kerebahan (tahan/tidak tahan rebah)

29. Ketahanan terhadap hama dan penyakit penting

\section{Hasil dan Pembahasan}

\section{Hasil}

A. Sorgum Kabupaten Limapuluh Kota

\begin{tabular}{|l|c|l|}
\hline Lokasi & $:$ & Tanjung Pati, Kab. Limapuluh Kota \\
\hline Kondisi lahan & $:$ & Datar dengan ketinggian \pm 500 di atas permukaan laut \\
\hline Jenis tanah & $:$ & Aluvial \\
\hline & & \\
\hline
\end{tabular}

\begin{tabular}{|c|c|c|}
\hline Deskripsi Tanaman & Karakter & Dokumentasi \\
\hline Sifat tanaman & Tidak menghasilkan anakan & \\
\hline Tinggi tanaman & $375-436 \mathrm{~cm}$ & \\
\hline Jumlah daun & $10-20$ helai & \\
\hline Bentuk daun & Pita & \\
\hline Panjang daun & $93-120 \mathrm{~cm}$ & \\
\hline Lebar daun & $6-8 \mathrm{~cm}$ & \\
\hline Sudut daun & $45^{\circ} \mathrm{C}$ & \\
\hline Warna daun & Hijau tua & \\
\hline Ujung daun & Runcing & \\
\hline Permukaan daun & Halus, licin tidak berbulu & \\
\hline
\end{tabular}




\begin{tabular}{|c|c|c|}
\hline Tepi daun & Lurus & \\
\hline Tulang daun & Rata & \\
\hline Lidah daun & Ada & \\
\hline Kerah daun & Ada & 1 \\
\hline Umur berbunga $50 \%$ & 70 hari & \\
\hline Kedudukan tangkai bunga & Ujung batang & \\
\hline Bentuk berbunga & Tunggal & \\
\hline Kepadatan malai & Agak longgar & \\
\hline Panjang malai & $20-30 \mathrm{~cm}$ & \\
\hline Leher malai & Menonjol, hijau & \\
\hline Bentuk malai & Piramida & \\
\hline Bentuk sekam & $50 \%$ tertutup & \\
\hline Warna sekam & Coklat tua & \\
\hline Warna biji & Coklat muda mengkilat & \\
\hline Bentuk biji & Bulat & \\
\hline Ukuran biji & $4,0 \times 4,0 \times 3,5 \mathrm{~mm}$ & \\
\hline Bobot 100 biji & $3,7-4,6 \mathrm{~g}$ & \\
\hline Kerebahan & Tahan rebah & \\
\hline $\begin{array}{l}\text { Ketahanan terhadap hama dan penyakit } \\
\text { penting }\end{array}$ & $\begin{array}{l}\text { Agak rentan penyakit karat daun yang } \\
\text { disebabkan Puccinia purpera }\end{array}$ & \\
\hline
\end{tabular}

\section{B. Sorgum Kabupaten Limapuluh Kota}

\begin{tabular}{|c|c|c|c|}
\hline Lokasi & : & \multicolumn{2}{|c|}{ H. Agus Salim No. 30, Kel Aur Kuning (Talago) Kecamatan Payakumbuh Selatan } \\
\hline Kondisi lahan & : & \multicolumn{2}{|c|}{ Datar dengan ketinggian $\pm 450 \mathrm{~m}$ di atas permukaan laut } \\
\hline Jenis tanah & : & \multicolumn{2}{|l|}{ Aluvial } \\
\hline \multicolumn{2}{|c|}{ Deskripsi Tanaman } & Karakter & Dokumentasi \\
\hline \multicolumn{2}{|c|}{ Sifat tanaman } & Tidak menghasilkan anakan/ratoon & \\
\hline \multicolumn{2}{|l|}{ Tinggi tanaman } & $250-350 \mathrm{~cm}$ & \\
\hline \multicolumn{2}{|l|}{ Jumlah daun } & 8-14 helai & \\
\hline
\end{tabular}




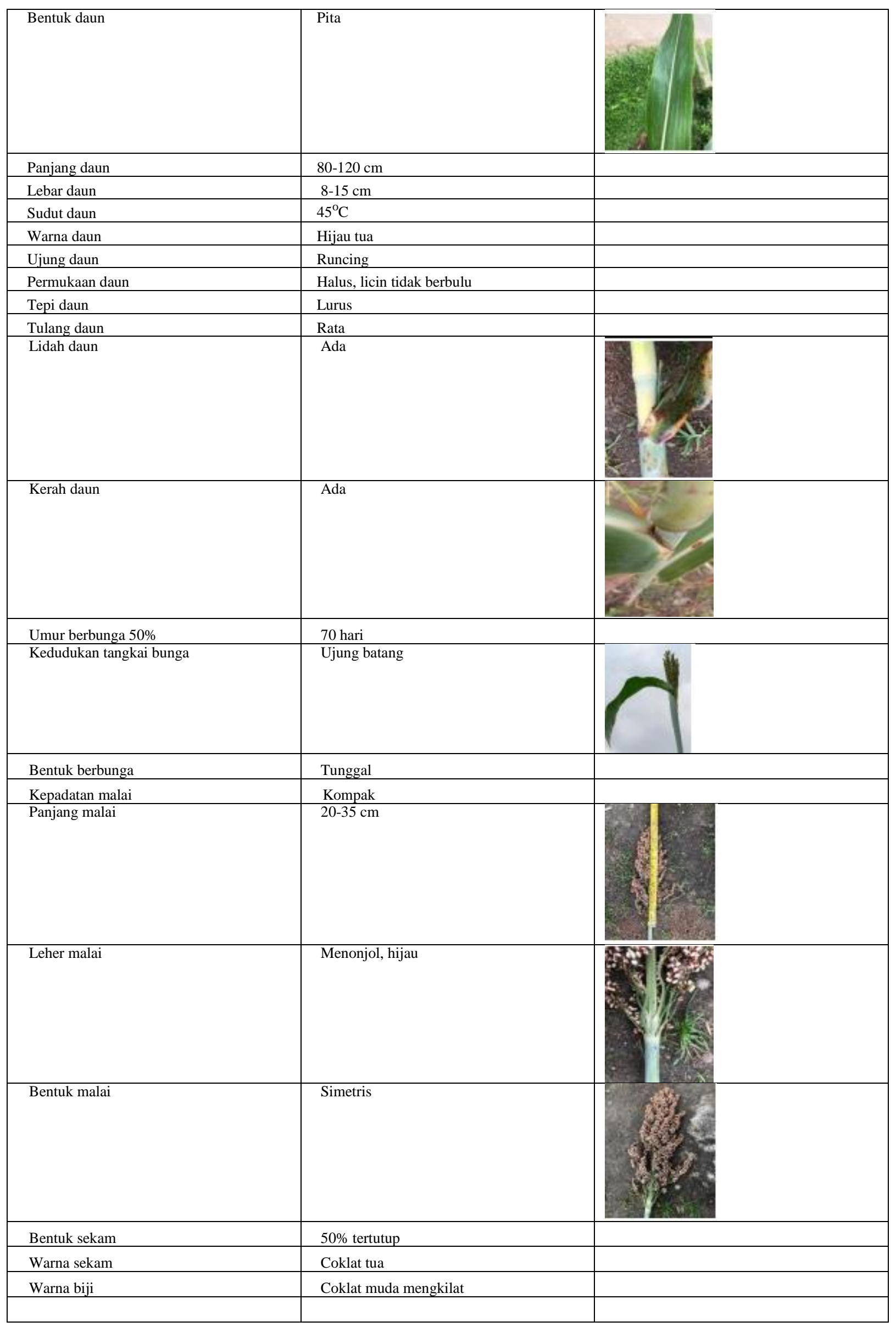




\begin{tabular}{|l|l|l|}
\hline Bentuk biji & Bulat pipih & \\
\hline Ukuran biji & $4,0 \times 2,5 \times 3,0 \mathrm{~mm}$ & \\
\hline Bobot 100 biji & $3,7-4,0 \mathrm{~g}$ & Rentan rebah \\
\hline Kerebahan & $\begin{array}{l}\text { Rentan penyakit karat daun yang } \\
\text { disebabkan Puccinia purpera }\end{array}$ & Retahanan terhadap hama dan penyakit \\
penting & disebabkan Colletrotrichum graminicola & \\
\hline & & \\
\hline
\end{tabular}

\section{Sorgum Kabupaten Sijunjung}

\begin{tabular}{|l|c|l|}
\hline Lokasi & $:$ & Nagari Tanjung Bonai Aur Selatan, Sumpur Kudus, Kabupaten Sijunjung \\
\hline Kondisi lahan & $:$ & Berbukit dengan ketinggian $\pm 1.250 \mathrm{~m}$ di atas permukaan laut \\
\hline Jenis tanah & $:$ & Podzolik Merah kuning \\
\hline & & \\
\hline
\end{tabular}

\begin{tabular}{|l|l|l|}
\hline \multicolumn{1}{|c|}{ Deskripsi Tanaman } & \multicolumn{1}{|c|}{ Karakter } & Dokumentasi \\
\hline Sifat tanaman & Menghasilkan anakan & \\
& & \\
\hline Tinggi tanaman & $250-340 \mathrm{~cm}$ & \\
\hline Jumlah daun & $8-14$ helai & \\
\hline Bentuk daun & Pita & \\
& & \\
\hline Panjang daun & & \\
\hline Lebar daun & & \\
\hline Sudut daun & & \\
\hline Warna daun & $80-120 \mathrm{~cm}$ & \\
\hline Ujung daun & $8-15 \mathrm{~cm}$ & \\
\hline Permukaan daun & $45^{\circ} \mathrm{C}$ & \\
\hline Tepi daun & Hijau tua & \\
\hline Tulang daun & Runcing & \\
\hline Lidah daun & Halus, licin tidak berbulu & \\
\hline & Lurus & \\
\hline & Menonjol & \\
\hline
\end{tabular}




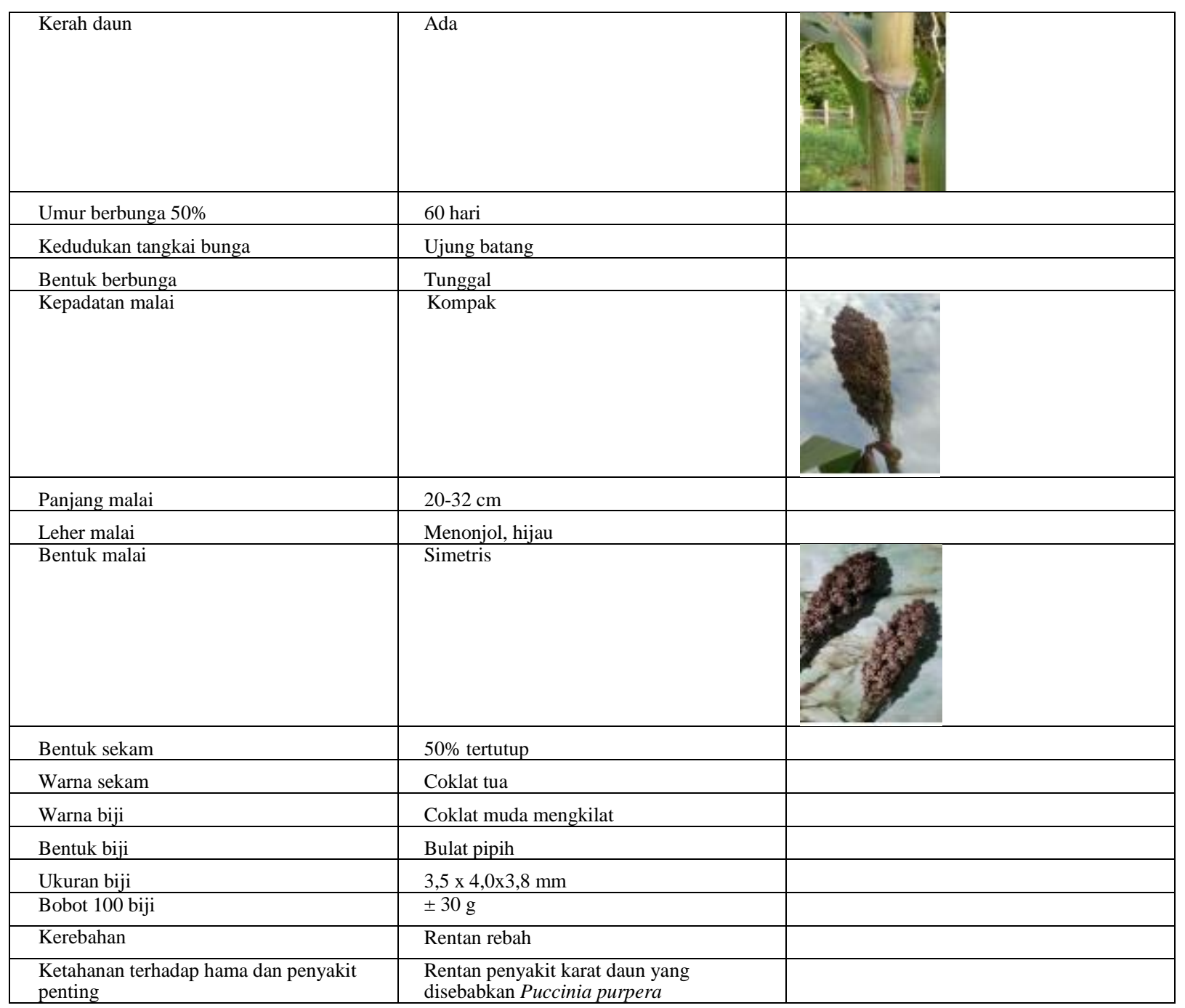

\section{Pembahasan}

Tanaman sorghum tersebar di tiga lokasi Sumatera Barat seperti daerah Kabupaten Limapuluh Kota, Kota Payakumbuh, dan Kabupaten Sijunjung. Tanaman sorgum tumbuh pada ketinggian yang rendah sampai tinggi, tergantung kepada varietas yang dibudidayakan. Pada periode tahun 1980-2013 telah dilepas 11 varietas unggul sorgum dengan daya hasil cukup tinggi, berumur genjah serta daya adaptasi yang luas (Subagio dan Aqil, 2013). Setiap daerah memperlihatkan karakteristik morfologi tanaman yang berbeda. Perbedaan morfologi (penampilan) tanaman di lapangan disebabkan karena adanya perbedaan susunan genetic dari varietas.

Sifat tanaman ada yang mempunyai anakan ada yang tidak. Plasma nutfah yang berasal dari Kabupaten Sijunjung memiliki anakan yang berarti dapat diratun, sehingga dapat digunakan sebagai bahan pemuliaan tanaman. Beberapa varietas sorgum memiliki kemampuan menghasilkan anakan seperti UPCASI, Sangkur, Badik, dan Keris (Setyowati, Hadiatmi, dan Sutoro, 2005).

Tinggi tanaman di lapangan jauh lebih tinggi dibandingkan dengan deskripsi sorgum. Tinggi tanaman lebih dipengaruhi oleh faktor lingkungan tumbuh.

Jumlah daun berbeda antara kab. Limapuluh dengan Kota Payakumbuh dan Kabupaten Sijunjung, warna daun bervariasi dari hijau muda sampai hijau tua, dan tulang daun ada yang menonjol ada yang tidak. 
Kepadatan malai bervariasi dari kompak, semi kompak dan agak longgar. Bentuk malai dari simetris sampai piramid. Panjang malai yang diukur dari leher malai ada yang pendek ada yang panjang. Bentuk dan warna leher malai ada yang menonjol ada yang rata dengan warna hijau.

Bobot 100 biji sorgum berbeda untuk ketiga lokasi, hal ini disebabkan ukuran biji yang berbeda. Perlu menghitung bobot biji per malai untuk mendapatkan produksi per hektar. Karakter bobot biji per malai dapat dijadikan karakter untuk perbaikan daya hasil (Trikoesoemaningtyas, Wirnas, Saragih, Rini, Sari, Marwiyah, dan Sopandie, 2017). Perbedaan varietas sorgum mempengaruhi pertumbuhan dan hasil tanaman (Cahyo, Hidayat, Sunyoto, dan Kamal, 2014).

Ketahanan terhadap hama dan penyakit utama tanaman sorgum setiap varietas berbeda. Sorgum di kota Payakumbuh rentan terhadap penyakit karat daun dan antraknosa. Menurut Muli, Hadi, dan Suharjo (2020) penyakit antraknosa merupakan utama sorgum yang berkembang pesat pada kondisi panas dan lembab. Kehilangan hasil akibat penyakit ini mencapai $50 \%$ tergantung kapan tanaman terinfeksi.

\section{Kesimpulan}

Tanaman sorghum tersebar di tiga daerah Sumatera Barat seperti Kabupaten Limapuluh Kota, Kota Payakumbuh, dan Kabupaten Sijunjung. Tanaman sorgum dapat tumbuh pada ketinggian yang rendah sampai tinggi. Setiap daerah memperlihatkan karakteristik morfologi tanaman yang berbeda. Karakteristik morfologi secara fenotipe berbeda antara tanaman sorgum dan paling mudah diteliti antara lain sifat tanaman, tinggi tanaman, warna daun, permukaan daun, tulang daun, kepadatan malai, bentuk malai,panjang malai mulai dari leher malai, bentuk dan warna leher malai. Ketahanan tanaman sorgum terhadap penyakit berbeda tergantung varietas dan lokasi penanaman.

\section{Daftar Pustaka}

Andriani, A. dan M. Isnaini. (2013). Morfologi dan fase pertumbuhan sorgum. Dalam Buku Sorgum: Inovasi Teknologi dan Pengembangan. IAARD Press, Jakarta. hal 47-68.

Cahyo, G.D., K.F. Hidayat, Sunyoto, dan M. Kamal. (2014). Pertumbuhan dan hasil tiga varietas sorgum (Sorghum bicolor (L.) Moench) Ratoon I pada kerapatan tanaman yang berbeda. J. Agrotek Tropika. 2(3): 400-407.

Dicko, M.H., H. Gruppen, A.S. Traoré, W.J.H. Van Berkel, and A.G.J. Voragen. (2006). Sorghum grain as human food in africa: Relevance of content of starch and amylase activities. African journal of biotechnology 5(5): 384-395.

$\mathrm{du}$ Plessis, J. (2008). Sorghum production. Republic of south africa department of agriculture. www.nda.agric.za/publications.

Hoeman, S. (2012). Prospek dan potensi sorgum sebagai bahan baku bioetanol. Pusat aplikasi teknologi isotop dan radiasi (PATIR) dan badan tenaga nuklir nasional (BATAN). Jakarta Selatan.

Irawan, B. dan N. Sutrisna. (2011). Prospek pengembangan sorgum di jawa barat mendukung diversifikasi pangan. Forum Penelitian Agro Ekonomi, 29(2): 99-113.

Karuppaiyan, R., B. Ram, dan M.R. Meena. (2011). Protection of plant varieties, breeders rights and farmers rights in India. Traning Manual. Plant variety journal of India 1(1).

Kusumawati, A., N.A. Putri, dan I. Suliansyah. (2013). Karakterisasi dan evaluasi beberapa genotype sorgum (Sorghum bicolor L.) di sukarami kabupaten solok. Jurnal Agroteknologi, 4(1): 7-12.

Muli, F.U., Efri, M.S. Hadi, dan R. Suharjo. (2020). Pengaruh penambahan pupuk mikro dan beberapa genotipe sorgum (Sorghum bicolor (L.) Moench) terhadap intensitas penyakit antraknosa (Colletotrichum sp.) di lahan petani tanjung bintang lampung selatan. J. Agrotek Tropika, 8(2): 347-354.

Prajapati, D.R., S.K. Pahuja, N.K. Verma, and S. 
Chaudhary. (2018). Morphological characterization of sorghum [sorghum bicolor (1.) moench] germplasm for dus traits. Int. J. Curr. Microbiol.App.Sci, 7(2): 2058-2071

Prassad, P.V.V. dan S.A. Staggenborg. (2013). Growth and production of sorghum and millets. soils, plant growth and crop production, vol. 2. Departement of Agronomy Kansas State University. www.eolss.net/ Eolss-sample AllChapter.aspx

Purwanto, Y. (2000). Etnobotani dan konservasi plasma nutfah hortikultura. Kebun Raya Bogor, Bogor.

Rahmawati. (2020). Morfologi Tanaman sorgum. Balai penelitian tanaman serealia. Kementerian Pertanian.

Rismunandar. (2006). Sorgum tanaman serba guna. Bandung: Sinar Baru. 71 hal.

Sihono, S. Human, W.M. Indriatama, Carkum, Parno, dan Tardisuseno. (2016). Perbaikan varietas sorgum manis melalui pemuliaan tanaman dengan teknik mutasi. Pusat aplikasi isotop dan radiasi, badan tenaga nuklir nasional. 9 hal.

Setyowati, M., Hadiatmi, dan Sutoro. (2005). Evaluasi pertumbuhan dan hasil plasma nutfah sorgum (sorghum vulgare (1.) moench.) dari tanaman induk dan ratoon. Buletin plasma nutfah, 11(2): 41-48.

Sirappa, M.P. (2003). Prospek pengembangan sorgum di indonesia sebagai komoditas alternatif untuk pangan, pakan, dan industri. Jurnal penelitian dan pengembangan pertanian, 22(4):133-140.

Slamet, A., Hisra, and Rajab. (2020). The characteristics of the morphological genotypes of local sorghum (sorghum bicolor (1.) moench) from buton selatan. Scientia Educatia: Jurnal pendidikan sains, 9(1): 8795.

Suarni. (2016). Peranan sifat fisikokimia sorgum dalam diversifikasi pangan dan industri serta prospek pengembangannya. Jurnal litbang pertanian, 35(3): 99-110.

Subagio, H. dan Aqil, M. (2013). Pengembangan produksi sorgum di indonesia. Seminar nasional inovasi teknologi pertanian, Halaman 199 - 214.

Trikoesoemaningtyas, D. Wirnas, E.L. Saragih, E.P. Rini, M. Sari, S. Marwiyah, dan D. Sopandie. (2017). Kendali genetik karakter morfologi dan agronomi pada tiga populasi sorgum (sorghum bicolor (1.) moench). J. Agron. Indonesia, 45(3): 285-291.

Waniska, R.D. (2000). Structure, phenolic compounds, and antifungal protein of sorghum caryopsis. In A. Chandrashekar, R. Bandyopadhyay, and A.J. Hall (eds.). Technical and institutional options for sorghum grain mold management: proceedings of an international consultation, 18-19 May 2000, ICRISAT, Patancheru 502 324, Andhra Pradesh, India: International Crops Research Institute for the Semi Arid Tropics. Pp 72-10 